\title{
DEVELOPMENT OF HEALTH MASSAGE TO IMPROVE WORKING PRODUCTIVITY WITH DAKSA DISABILITIES
}

\author{
Sumarjo $^{1}$, Sigit Nugroho ${ }^{1 *}$, Aris Fajar Pambudi ${ }^{1}$ \\ ${ }^{1}$ Ilmu Keolahragaan, Fakultas Ilmu Keolahragaan Universitas Negeri Yogyakarta Jl. Colombo No. 1, \\ Karangmalang Depok, Sleman, Yogyakarta, Indonesia \\ sumarjofik@uny.ac.id, *sigit.nugroho@uny.ac.id, arisfajarpambudi@uny.ac.id
}

\begin{abstract}
This development research by modifying the form of massage. The phase being developed is related to health massage which is expected to increase productivity and provide suitable techniques for disabled persons with lower limbs. The research objective is to develop a form of health massage so that it can increase work productivity for persons with disabilities. The specific target in the research is to find the right health massage techniques and patterns for people with disabilities in increasing work productivity. The target of this research is designed through three stages, namely survey research, development research, and experimental research. The subjects of the study were persons with disabilities with monoplegia disabilities in Yogyakarta Special Region. Based on the research results, it can be concluded that the perception of the form of health massage is very good and feasible to be applied. In addition, massage is effective for dealing with health and overcoming complaints of pain. The specifications for the form of health massage are body position consisting of three positions, namely face down on your back and sitting. In a prone position starting from the left starting from the bottom, namely the left leg. In the supine position massage starts from the left foot and toes. In a sitting position massage starts from the right shoulder. The techniques used from these three positions use friction, petrisage, tapotement, walken, skin rolling and effleurage. In addition, the massage applied is safe for persons with disabilities, safe in dealing with health and safe for increasing work productivity which consists of motivation, knowledge, skills, and attitudes.
\end{abstract}

Keywords: health massage, work productivity, disability

\section{PENGEMBANGAN MASASE KESEHATAN UNTUK MENINGKATKAN PRODUKTIVITAS KERJA DISABILITAS TUNA DAKSA}

\begin{abstract}
Abstrak
Penelitian pengembangan ini dengan memodifikasi bentuk masase. Masase yang dikembangan berkaitan dengan masase kesehatan yang diharapkan dapat meningkatkan produktivitas dan memberikan teknik yang sesuai untuk disabilitas tuna daksa yang mengalami cacat bagian bawah. Tujuan penelitian untuk mengembangkan bentuk masase kesehatan sehingga dapat meningkatkan produktivitas kerja bagi penyandang disabiliatas tuna daksa. Target khusus dalam penelitian menemukan teknik dan pola masase kesehatan yang tepat bagi para disabiliatas tuna daksa dalam meningkatkan produktivitas kerja. Target penelitian ini dirancang melalui tiga tahap yaitu penelitian survey, penelitian pengembangan, dan penelitian eksperimental. Subyek penelitian penyandang disabilitas tuna daksa monoplegia di Daerah Istimewa Yogyakarta. Berdasarkan hasil penelitian dapat disimpulkan bahwa persepsi bentuk masase kesehatan sangat baik dan layak untuk diterapkan. Selain itu masase yang diterapkan efektif untuk mengatasi kesehatan serta mengatasi keluhan rasa sakit. Spesifikasi bentuk masase kesehatan yaitu posisi badan terdiri dari tiga posisi, yaitu telungkup terlentang dan duduk. Pada posisi telungkup dimulai dari sebelah kiri diawali dari bawah yaitu bagian kaki kiri. Pada posisi terlentang masase diawali dari kaki dan jari-jari kaki sebelah kiri. Pada posisi duduk masase diawali dari bahu sebelah kanan. Teknik yang dipakai dari ketiga posisi
\end{abstract}


tersebut menggunakan friction, petrisase, tapotement, walken, skin rolling dan effleurage. Selain itu masase yang diterapkan aman untuk penyandang disabilitas tuna daksa, aman dalam mengatasi kesehatan dan aman untuk meningkatkan produktifitas kerja yang teridiri dari motivasi, pengetahuan, keterampilan, dan sikap.

Kata Kunci : masase kesehatan, produktivitas kerja, disabilitas

\section{PENDAHULUAN}

Bangsa Indonesia sedang berupaya meningkatkan kualitas hidup sumber daya sebagai persiapan untuk menuju masyarakat yang maju berkelanjutan. Pengetahuan dan keterampilan yang diperoleh melalui pendidikan memberi bekal untuk berperan dalam kegiatan pembangunan, terutama dalam lingkungan keluarga. Program kesehatan masyarakat memberikan prioritas pada upaya peningkatan kesehatan masyarakat dan keluarga serta pencegahan terhadap penyakit. Pembangunan kesehatan merupakan bagian integral dari pembangunan sumber daya manusia (SDM), untuk mencapai pembangunan bangsa yang maju, mandiri serta sejahtera lahir dan batin. Pembangunan SDM mulai dari kandungan bahkan jauh sebelumnya dengan memperhatikan tingkat kesejahteraan para calon ibu kemudian bayi, anak balita, usia prasekolah dan usia sekolah, pemuda, usia produktif sampai usia lanjut.

Usaha untuk meningkatkan kesehatan masyarakat menjadi program utama dalam rangka peningkatan kualitas hidup keluarga melalui pendidikan masyarakat. Dalam kaitan ini peran keluarga dan sekolah menjadi penting, sebagai perwujudan cita-cita yang dirumuskan dalam tujuan pembangunan nasional. Perwujudan generasi yang berkualitas untuk pembangunan bangsa dan negara termasuk untuk para penyandang disabilitas. Para penyandang disabilitas kerap kali terisolir secara sosial dan menghadapi diskriminasi dalam akses atas kesehatan, layanan pendidikan dan pekerjaan. Perilaku kesehatan sesuai pendapatnya Albarracin et al (2001) merupakan semua aktivitas atau kegiatan seseorang, baik yang dapat diamati maupun yang tidak dapat diamati yang berkaitan dengan pemeliharaan dan peningkatan kesehatan. Perilaku kesehatan didefinisikan oleh Sulaeman (2016) merupakan kegiatan yang dilakukan individu, terlepas dari status kesehatan yang nyata atau dirasakan, untuk tujuan mempromosikan, melindungi atau menjaga kesehatan. Sedangkan Skinner (2000) menyatakan bahwa perilaku kesehatan sebagai respon seseorang terhadap stimulus atau objek yang berhubungan dengan sehat-sakit dan penyakit serta faktor-faktor yang mempengaruhi kesehatan seperti lingkungan, makanan, minuman, dan pelayanan kesehatan. Perilaku kesehatan diperjelas oleh pendapatnya Sarwono (2007) yang menyatakan bahwa perilaku kesehatan merupakan segala bentuk pengalaman dan interaksi individu dengan lingkungannya.

Promosi kesehatan merupakan proses membuat orang mampu meningkatkan kendali terhadap determinan kesehatan dan memperbaiki kesehatan mereka. Salah satu tujuan promosi kesehatan mengubah perilaku atau memberikan informasi kepada sasaran untuk menuju ke suatu perilaku yang lebih baik atau memberikan gambaran keuntungan berperilaku yang positif dan kerugian berperilaku negatif. Status kesehatan masyarakat ditentukan oleh kondisi kesehatan para warganya antara lain kondisi orang tua, remaja dan anak-anak. Undang-Undang No. 36 Tahun 2009 tentang Kesehatan memberikan batasan: "kesehatan adalah keadaan sehat baik secara fisik, mental, spiritual maupun sosial yang memungkinkan setiap orang untuk hidup produktif secara sosial dan ekonomi”. Batasan yang merujuk pada batasan kesehatan menurut Organisasi Kesehatan Dunia (WHO) yang paling baru, memang lebih luas dan dinamis dibandingkan dengan batasan sebelumnya yang mengatakan, bahwa kesehatan adalah keadaan sempurna, baik fisik, mental, maupun sosial, dan tidak hanya bebas dari penyakit dan cacat. 
Pada batasan yang terdahulu, kesehatan itu hanya mencakup tiga aspek, yakni: fisik, mental, dan sosial, namun menurut UU No. 36 Tahun 2009 tentang kesehatan, kemudian kesehatan itu mencakup lima aspek yakni fisik (badan), mental (jiwa), sosial, spiritual, ekonomi (produktif). Hal ini berarti kesehatan seseorang tidak hanya diukur dari aspek fisik, mental, spiritual, dan sosial saja, tetapi juga diukur dari produktivitasnya dalam arti mempunyai pekerjaan atau menghasilkan secara ekonomi. Bagi yang belum memasuki usia kerja, anak dan remaja; atau bagi yang sudah tidak bekerja (pensiun) atau usia lanjut, berlaku produktif secara sosial, yakni mempunyai kegiatan, misalnya sekolah atau kuliah bagi anak dan remaja, dan kegiatan pelayanan sosial bagi usia lanjut. Kelima dimensi kesehatan tersebut saling berpengaruh dalam mewujudkan tingkat kesehatan pada seseorang, kelompok, atau masyarakat. Itulah sebabnya, kesehatan itu bersifat holistik atau menyeluruh.

data Sakernas penduduk usia kerja disabilitas nasional berjumlah 21.930 .529 orang. Dari total tersebut data yang termasuk angkatan kerja sebanyak 11.224 .673 orang $(51,18$ persen), untuk angkatan kerja disabilitas yang bekerja sebanyak 10.810.451 ( 96,31 persen) dan pengganggur terbuka sebanyak 414.222 orang (3,69 persen). Sedangkan yang bukan angkatan kerja penyandang disabilitas sebanyak 10.705 .856 (48.82 persen). Data disabilitas yang berada di bangku sekolah sebanyak 206.163 orang (1,93 persen), yang mengurus rumah tangga sebanyak 5.911.017 orang (55,21 persen) dan lain-lain sebanyak 4.588.676 orang (42.86 persen). Dari data tersebut terlihat bahwa masih ada pengangguran bagi disabilitas nasional sebesar 3,69 \%, maka masih sangat dibutuhkan peran pemerintah dan lembaga serta para pemerhati disabilitas untuk mendukung program pengentasan pengganguran (Nurahman, 2018) . Langkah pemberdayaan untuk peningkatan kemampuan masyarakat dapat membuat mereka menjadi lebih berdaya, dalam arti mampu melakukan yang bermanfaat dalam pembangaunan masyarakat. Pada dasarnya penyandang disabilitas memiliki potensi dan kemauan untuk berubah ke arah yang lebih baik sesuai dengan potensi sumber daya alam dan kearifan lokal di sekitar mereka.

Persepsi masyarakat terhadap penyadang disabilitas yang sudah tertanam berabadabad sulit dihilangkan begitu saja. Misalnya, mahasiswa disabilitas ada yang ditolak untuk tinggal dalam satu rumah kost, karena pemiliknya menganggap keberadaan penyandang disabilitas akan mendatangkan musibah bagi usaha mereka. Dalam menggunakan transportasi udara dengan pesawat terbang komersial, penyandang disabilitas harus menandatangani pernyataan sakit sehingga tidak ditanggung asuransinya. Masyarakat disabilitas berasal dari bahasa Inggris yaitu people with different abilities yaitu masyarakat yang memiliki kemampuan yang berbeda dengan masyarakat normal baik secara fisik maupun mental (Deswanto, 2004). Segala keterbatasan yang dimiliki oleh masyarakat tersebut tidak dapat dijadikan alasan bagi mereka atau siapapun untuk melakukan pembatasan sosial baik secara langsung maupun tak langsung. Pembatasan sosial terjadi ketika mereka yang memiliki keterbatasan fisik dikelompok-kelompokan dalam yayasan penyandang cacat ataupun pada sekolah luar biasa. Pembatasan sosial ini semakin nyata ketika lingkungan di sekitar kita, ruang-ruang publik kota justru menyebabkan setiap langkah alat bantu berjalan tersandung, setiap putaran kursi roda terhenti, setiap ayunan tongkat putih tunanetra terganjal, dan setiap bahasa isyarat tidak dipedulikan masyarakat. Istilah masyarakat disabilitas tidak terbatas pada mereka penyandang cacat tetapi istilah disabilitas memiliki pengertian yang lebih luwes dan luas yaitu orang yang memiliki hambatan sementara maupun permanen dalam menjalankan aktivitas keseharian mereka, termasuk di dalamnya ibu hamil, anak-anak, lanjut usia, pengguna kursi roda, kruk, tunanetra, tunarungu dan tunadaksa.

Di Indonesia, untuk mengembangkan kemandirian kaum disabilitas melalui beberapa cara seperti upaya berwirausaha dari sejumlah penyandang cacat. Di Yogyakarta, telah 
dirintis usaha ojek motor modifikasi yang dijalankan oleh penyandang cacat untuk komunitas penyandang cacat dan masyarakat umum. Tribun Jogja (Anonim, 2016) mengungkapkan bahwa tersedia layanan ojek yang berlabel Dhifa CT (City Tour and Transport) yang dikelola oleh kaun disabilitas. Layanan ini merupakan wadah kemandirian dari kaum disabilitas yang ingin membuktikan bahwa penyandang cacat bisa memasuki dunia kerja dan menghilangkan diskriminasi kaum disabilitas dalam dunia kerja. Data WHO (2005), sekitar 10 persen atau kurang lebih 24 juta dari jumlah total penduduk Indonesia merupakan masyarakat yang memiliki kemampuan terbatas dan mengalami fenomena permasalahan yang hampir sama berkaitan dengan hak terhadap penyediaan ruang-ruang publik yang tidak menjangkau dan belum bisa melayani kebutuhan spesifik aktivitas mereka (Deswanto, 2004).

Upaya peningkatan produktivitas kerja kaum disabilitas sudah diupayakan oleh Pemerintah Indonesia melalui pemberian berbagai keterampilan. Misalnyai program di Balai Rehabilitasi Penyandang Tuna Daksa, para penyandang tuna daksa dilatih untuk memiliki bermacam keterampilan. Produktivitas sendiri merupakan suatu kemampuan untuk menghasilkan sesuatu. Tingkat produktivitas yang tinggi, ada beberapa faktor pendukung terbentuknya produktivitas yang tinggi untuk kaum disabilitas. Faktor pendukung tersebut diantaranya: Pendidikan, keterampilan, sikap dan etika kerja, tingkat penghasilan, jaminan sosial, tingkat sosial dan iklim kerja, motivasi, gizi dan kesehatan, hubungan individu, teknologi, dan produksi. Pemberian keterampilan bagi kaum disabilitas merupakan pemenuhan kebutuhan yang sesuai dengan kebutuhan berdasarkan potensi yang dimiliki dan dapat lebih ditingkatkan menuju kemandirian. Melalui program pengembangan masase kesehatan yang ditujukan untuk kaum disabilitas diharapkan para kaum disabilitas memiliki kualitas hidup yang lebih layak dan dapat mehilangkan persepsi bahwa kaum disabilitas hanya akan menjadi beban hidup bagi masyarakat dengan meminta-minta di beberapa tempat.

\section{METODE}

Jenis penelitian ini merupakan penelitian dan pengembangan yang berorientasi pada produk. Prosedur penelitian dan pengembangan didasarkan pada dua tujuan utama, yaitu: (1) mengembangkan produk dan, (2) menguji keefektifan produk untuk mencapai tujuan (Sugiyono, 2018). Tujuan pertama disebut sebagai fungsi pengembangan sedangkan tujuan kedua disebut sebagai fungsi validasi. Secara keseluruhan penelitian ini akan menggunakan jenis rancangan penelitian, yaitu (1) deskriptif (2) pengembangan (3) eksperimental. Pada penelitian ini baru sampai pada tahap yang kedua yaitu pengembangan. Rincian jenis rancangan, subyek, variabel, instrumen, dan analisis data penelitian disajikan sebagai berikut.

\section{Penelitian Survey}

\section{Rancangan Penelitian}

Rancangan penelitian pada tahap pertama menggunakan jenis penelitian deskriptif yang dilakukan dengan metode survey. Survey bertujuan untuk memperoleh data analisis kebutuhan bentuk masase kesehatan yang berbasis produktivitas kerja, persepsi tenaga masase, tenaga kesehatan, dan penyandang tuna daksa tentang bentuk masase kesehatan yang berbasis produktivitas kerja pada penyandang disabilitas tuna daksa.

\section{Subyek Penelitian}

Subyek penelitian survey ini meliputi tuna daksa monoplegia putra dan putri, pakar masase, dan tenaga kesehatan. Lokasi dan subyek penelitian survey disajikan pada tabel 1 berikut: 
MEDIKORA, Vol. 19 No. 2 Oktober 2020 - 75

Sumarjo, Sigit Nugroho, Aris Fajar Pambudi

\begin{tabular}{ccc} 
TEMPAT & $\begin{array}{c}\text { Tabel 1. Subyek Penelitian } \\
\text { TUNA DAKSA }\end{array}$ & PAKAR \\
\hline UNY & 20 & $\begin{array}{c}\text { Masase } \\
\text { Kesehatan } \\
\text { Disabilitas }\end{array}$ \\
\hline Jumlah & 20 & 3
\end{tabular}

\section{Variabel Penelitian}

Berdasarkan pemahaman, persepsi, dan analisis kebutuhan, berikut disajikan variabel, indikator, dan jenis instrumen pada tabel 2 berikut:

Tabel 2. Variabel, indikator dan pengukuran penelitian dengan survey

\begin{tabular}{llll}
\hline No & Variabel & \multicolumn{1}{c}{ Indikator } & Pengukuran \\
\hline 1 & $\begin{array}{l}\text { Persepsi ahli dan } \\
\text { penyandang tuna daksa }\end{array}$ & $\begin{array}{l}\text { Tanggapan ahli terhadap bentuk } \\
\text { masase kesehatan } \\
\text { Tanggapan penyandang tuna daksa } \\
\text { terhadap bentuk masase kesehatan }\end{array}$ & Angket \\
\hline \multirow{2}{*}{$\begin{array}{l}\text { Kebermanfaatan masase } \\
\text { kesehatan berbasis } \\
\text { produktivitas kerja }\end{array}$} & $\begin{array}{l}\text { Alasan perlunya masase kesehatan } \\
\text { Bentuk masase kesehatan berbasis } \\
\text { produktivitas kerja meliputi: motivasi, } \\
\text { pengetahuan, keterampilan, dan sikap }\end{array}$ & Angket \\
\hline \multirow{2}{*}{$\begin{array}{l}\text { Spesifikasi teknik masase } \\
\text { kesehatan berbasis } \\
\text { produktivitas kerja }\end{array}$} & $\begin{array}{l}\text { Spesifikasi teknik masase kesehatan } \\
\text { menurut pakar masase }\end{array}$ & $\begin{array}{l}\text { Spesifikasi teknik masase kesehatan } \\
\text { menurut pakar kesehatan } \\
\text { Spesifikasi teknik masase kesehatan) } \\
\text { menurut penyandang tuna daksa }\end{array}$ & $\begin{array}{l}\text { Focus Group } \\
\text { Discusion } \\
\text { (FGD) }\end{array}$ \\
\hline
\end{tabular}

\section{Instrumen Penelitian}

Instrumen untuk mengukur variabel-variabel penelitian disusun sendiri berdasarkan variabel dan indikator penelitian. Sebelum instrumen tersebut digunakan, terlebih dahulu dilakukan uji validitas dan reliabilitas.

\section{Analisis Data}

Data yang diperoleh dianalisis menggunakan statistik deskriptif. Hasil analisis data digunakan sebagai dasar mengembangkan produk yang dilakukan pada tahap kedua.

\section{Penelitian Pengembangan}

\section{Rancangan Penelitian}

Rancangan pengembangan dilakukan pada tahap kedua, bertujuan untuk menyusun bentuk masase kesehatan yang telah dispesifikasikan pada tahap pertama. Produk yang akan dikembangkan meliputi: bentuk masase kesehatan pada penyandang tuna daksa monoplegia yang mengikuti program di BRTPD DIY. Secara rinci prosedur pengembangan bentuk masase kesehatan mengikuti model RPPT (Research Planning, Production, Testing (Sugiyono, 2018).

\section{Subyek Penelitian}

Subyek penelitian pada pengembangan melibatkan pakar yang terdiri atas: (1) tenaga masase, (2) tenaga kesehatan, dan (3) tuna daksa.

\section{Variabel Penelitian Pengembangan}

Berdasarkan kegiatan yang akan dilakukan berupa pengembangan produk variabelBerdasarkan kegiatan yang akan dilakukan berupa pengembangan produk variabel-variabel 
penelitian atau spesifikasi produk yang akan dikembangkan berupa bentuk masase kesehatan dalam meningkatkan produktivitas kerja, yaitu sebagai berikut:

1) Produk dalam bentuk masase kesehatan yang dikembangkan dengan menggabungkan berbagai teknik masase olahraga (sport massage) dan tenik masase sirkulasi (circulo massage) yang dapat meningkatkan produktivitas kerja

2) Produktivitas kerja yang ingin diketahui yaitu: (1) motivasi, (2) pengetahuan, (3) keterampilan, dan (4) sikap.

\section{Instrumen Penelitian}

Instrumen penelitian dalam penelitian pengembangan digunakan pada kegiatan evaluasi formatif. Instrumen disusun sendiri oleh peneliti. Isi instrumen terdiri atas teknikteknik masase kesehatan dalam meningkatkan produktivitas kerja terdiri dari dua hal pokok yaitu : (1) ketepatan teknik masase dan (2) efisiensi dalam melakukan masase.

\section{Analisis Data}

Data yang diperoleh melalui angket pada tinjauan pakar dianalisis menggunakan statistik deskriptif. Hasil analisis data digunakan sebagai dasar untuk melakukan revisi.

\section{HASIL DAN PEMBAHASAN}

\section{Hasil Penelitian}

\section{Penelitian Survei}

Berdasarkan hasil pengamatan peneliti berikut analisis kebutuhan yang harus dipenuhi dalam pengembangan masase kesehatan.

\section{Analisis Materi}

Analisis materi yang telah dilakukan antara lain melakukan studi pendahuluan berupa studi literatur dan melakukan observasi serta mengadakan wawancara kepada beberapa ahli masase dan kesehatan baik dari segi materinya dan segi pelatihannya yang dilakukan di Fakultas Ilmu Keolahragaan. Hasil yang sudah dicapai dalam studi pendahuluan tersebut berupa identifikasi permasalahan-permasalahan yang berkaitan dengan bentuk masase kesehatan, dimana belum ada bentuk masase kesehatan yang dilakukan oleh para penyandang tuna daksa baik dari segi materinya dan pelatihan yang secara lengkap membahas jenis masase kesehatan yang meliputi tanggapan, kebermanfaatan, dan spesifikasi teknik masase kesehatan. Hasil ini kemudian dijadikan sebagai masukan dalam membuat rencana atau proposal penelitian.

Hasil seperti tersebut di atas kemudian dijadikan sebagai masukan untuk mendeskripsikan dan menganalisis kebutuhan pengembangan masase kesehatan pada penelitian tahap pertama. Di samping itu, dalam langkah persiapan juga dilakukan penyiapan materi dan bahan serta sarana dan prasarana yang akan diperlukan dalam penelitian.

\section{Hasil Survey bentuk masase kesehatan}

1) Persepsi

Tanggapan para penyandang disabilitas, pendamping dan ahli tentang bentuk masase kesehatan yaitu sangat baik dan layak untuk diterapkan. Secara keseluruhan baik para penyandang, pendamping dan para ahli memiliki tanggapan yang sama bahwa bentuk masase kesehatan mudah untuk diikuti, penjabaran materi jelas dan mudah dipahami, masase kesehatan yang diikuti sesuai dengan kemampuan. Selain itu masase yang diterapkan efektif untuk meningkatkan produktifitas kerja, teknik masase efektif untuk mengatasi kesehatan dan keluhan rasa sakit. Masase yang diterapkan aman untuk penyandang disabilitas tuna daksa, masase yang diterapkan aman dalam mengatasi kesehatan dan aman untuk meningkatkan produktifitas kerja. 


\section{2) Kebermanfaatan}

Masase kesehatan yang diterapkan sangat bermanfaat untuk penyandang disabilitas tuna daksa. Urutan teknik masase yang diterapkan sangat bermanfaat untuk mengatasi kesehatan, mengatasi keluhan rasa sakit dan dapat mengatasi kelelahan. Selain itu masase yang diterapkan sangat bermanfaat untuk meningkatkan produktifitas kerja. Produktifitas kerja yang dapat ditingkatkan meliputi: (1) motivasi, (2) pengetahuan, (3) keterampilan, dan (4) sikap.

3) Spesifikasi bentuk masase kesehatan

Spesifikasi bentuk masase kesehatan terdiri dari tiga posisi, yaitu Telungkup, terlentang dan duduk. Pada posisi telungkup dimulai dari sebelah kiri diawali dari bawah yaitu bagian kaki kiri. Urutan bagian-bagian tubuh yang dimasase pada saat posisi telungkup, diantaranya: telapak kaki, pergelangan kaki, betis kaki, paha, pantat dan punggung. Teknik yang digunakan friction, petrisase, tapotement, walken dan effleurage.

Pada posisi terlentang masase diawali dari kaki dan jari-jari kaki sebelah kiri. Urutan bagian-bagian tubuh yang dimasase pada saat posisi terlentang, diantaranya: punggung dan jari-jari kaki, betis, paha, punggung tangan, telapak tangan, lengan bawah, lengan atas, perut, dada dan dahi atau muka. Teknik yang digunakan diantaranya friction, petrisase, effleurage lurus, dan effleurage menyilang. Sedangkan pada posisi dudk masase diawali dari bahu sebelah kanan. Urutan bagian yang dimasase pada posisi duduk, yaitu bahu dan kepala. Teknik yang digunakan diantaranya fiction, tapotement, skin rolling dan effleurage.

\section{Penelitian Pengembangan}

Secara garis besar langkah-langkah yang telah dilakukan antara lain sebagai berikut:

\section{Membuat materi dan urutan teknik bentuk masase kesehatan}

Bentuk materi dan urutan teknik masase kesehatan berbasis produktifitas kerja bagi disabilitas tuna daksa merupakan modifikasi bentuk masase antara teknik masase olahraga (sport massage) dan masase sirkulasi (circulo massage) yang sifatnya rehabilitasi atau terapi ke teknik masase yang sifatnya kesehatan, akan tetapi tidak merubah teknik yang sudah ada di dalam kedua jenis masase tersebut. Pengembangan masase kesehatan diharapkan bisa meningkatkan produktivitas dan memberikan teknik yang sesuai untuk penyandang disabilitas khususnya tuna daksa yang mengalami cacat pada anggota gerak bagian bawah. Materi dan urutan teknik bentuk masase kesehatan, yaitu sebagai berikut:

Posisi badan pada masase kesehatan terdiri dari dua posisi, yaitu telungkup dan terlentang.

1) Posisi Telungkup

Posisi telungkup dimulai dari sebelah kiri diawali dari bawah yaitu bagian kaki kiri. Urutan bagian-bagian tubuh yang dimasase pada saat posisi telungkup, diantaranya: Telapak kaki, urutan tekniknya sebagai berikut: friction, petrisase, tapotement, dan effleurage. Pergelangan kaki, tekninya hanya effleurage. Betis kaki, urutan tekniknya sebagai berikut: friction, petrisase, tapotement, dan effleurage. Paha, urutan tekniknya sebagai berikut: friction, petrisase, tapotement, dan effleurage. Pantat, urutan tekniknya sebagai berikut: friction, tapotement, dan walken. Punggung, urutan tekniknya sebagai berikut: friction, tapotement, walken dan effleurage.

2) Posisi Terlentang

Masase diawali dengan kaki dengan daerah manupulasi dari jari-jari kaki sebelah kiri. Urutan bagian-bagian tubuh yang dimasase pada saat posisi terlentang, diantaranya: Punggung dan jari-jari kaki, urutan tekniknya sebagai berikut: friction, petrisase, effleurage lurus, effleurage menyilang dan effleurage jari-jari kaki. Betis depan, urutan tekniknya sebagai berikut: friction, petrisase, dan effleurage. Paha depan, urutan tekniknya sebagai 
berikut: friction, petrisase dan effleurage. Punggung Tangan kiri, urutan tekniknya sebagai berikut: friction, petrisase, effleurage lurus, effleurage menyilang dan effleurage jari-jari tangan. Telapak tangan, urutan tekniknya sebagai berikut: friction dan effleurage. Lengan bawah, urutan tekniknya sebagai berikut: friction dan effleurage. Lengan atas, urutan tekniknya sebagai berikut: friction, petrisase dan effleurage. Perut, urutan tekniknya sebagai berikut: friction dan effleurage. Dada, urutan tekniknya sebagai berikut: friction, effleurage menyilang dan effleurage. Dahi dan Muka, urutan tekniknya sebagai berikut: effleurage lurus dan effleurage samping.

\section{3) Posisi Duduk}

Masase diawali dari daerah bahu sebelah kanan. Urutan bagian-bagian tubuh yang dimasase pada saat posisi terlentang, diantaranya: Bahu, urutan tekniknya sebagai berikut: friction, tapotement, dan effleurage. Kepala, urutan tekniknya sebagai berikut: friction, skin rolling, tapotement, dan effleurage.

\section{Validasi Rancangan}

Rancangan produk divalidasi oleh tim peneliti dan pakar masase, kesehatan dan disabilitas yang terdiri dari 3 orang peneliti, 1 pakar kesehatan, 1 pakar masase dan 1 pakar disabilitas. Dari validasi tersebut diperoleh masukan dari beberapa pakar diantaranya:

1) Perlu kejelasan klasifikasi disabilitas tuna daksa.

2) Perlu dibuat 3 porsi atau jenis bentuk masase berdasarkan jumlah teknik, waktu dan jenis kecacatannya, yaitu (1) bentuk masase yang tekniknya menyeluruh, yang waktunya 60 menit dan digunakan untuk tuna daksa ringan, (2) bentuk masase yang tekniknya sebagian atau setengah, yang waktunya 30 menit dan digunakan untuk tuna daksa sedang, dan (3) bentuk masase yang tekniknya sedikit, yang waktunya 15 menit dan digunakan untuk tuna daksa ganda.

3) Urutan posisi badan dari telungkup setelah punggung sebelum terlentang langsung menuju ke tangan.

\section{Sosialisasi bentuk masase kesehatan}

Sosialiasai bentuk masase kesehatan diberikan kepada para penyandang disabilitas tuna daksa yang berada di Balai Rehabilitasi Terpadu Penyandang Disabilitas (BRTPD) DIY yang berjumlah 24 orang. Selain penyandang disabilitas tuna daksa sosialisasi diberikan kepada para pendamping disabilitas yang berjumlah 4 orang.

\section{Pembahasan}

Hasil dari penelitian survei bahwa tanggapan para penyandang disabilitas, pendamping dan ahli tentang bentuk masase kesehatan yaitu sangat baik dan layak untuk diterapkan. Masase yang diterapkan aman untuk penyandang tuna daksa dan aman dalam menagatsi kesehatan serta dapat meningkatkan produktivitas kerja. Produktivitas kerja yang dapat ditingkatkan meliputi motivasi, pengetahuan, keterampilan dan sikap. Produktivitas merupakan perbandingan hasil yang dicapai dengan peran tenaga kerja per satuan waktu (Riyanto, 2006). Produktivitas pendapatnya Hasibuan (2009) merupakan perbandingan antara hasil (output) dengan masukan (input). Dewan produktivitas nasional mempunyai pengertian bahwa produktivitas sebagai sikap mental yang selalu berpandangan bahwa mutu kehidupan hari ini harus lebih baik dari kemaren dan esok harus lebih baik dari hari ini. Filosofi dan spirit tentang produktivitas sudah ada sejak awal peradapan manusia karena makna produktivitas adalah ingin (the will) dan upaya (effort) manusia untuk selalu meningkatkan kualitas kehidupan dan penghidupan di segala bidang.

Secara umum produktivitas merupakan perbandingan antara keluaran (output) yang dicapai dengan masukan (input) yang dibutuhkan untuk memproduksi output tersebut (Purnama, 2008, p.63). Sedarmayanti (2001, p.12) menyatakan bahwa berbagai faktor yang 
mempengarui produktivitas kerja antara lain sikap mental berupa motivasi kerja, disiplin kerja dan etika kerja, pendidikan, keterampilan, manajemen, tingkat pengjhasilan, kesehatan, jaminan sosial, lingkungan sosial iklim kerja, sarana produksi, teknologi dan kesempatan berprestasi. Faktor-faktor pembentuk produktivitas yang tinggi diantaranya adalah: pendidikan, keterampilan, sikap dan etika kerja, tingkat penghasilan, jaminan sosial, lingkungan kerja dan iklim kerja, motivasi, disiplin kerja, gizi dan kesehatan, manajemen, teknologi dan sarana produksi, serta kesempatan berprestasi (Ravianto, 2005). Sedangkan Djati (2009) menyatakan bahwa produktivitas merupakan sebagai tingkatan efiensi dalam memproduksi barang dan jasa, produktivitas mengutarakan cara pemanfaatan secara baik terhadap sumber-sumber dalam memproduksi barang (Djati, 2009). Peningkatan produktivitas kerja dapat dilakukan dengan pemberian masase. Teknik masase kesehatan yang diterapkan sangat bermanfaat untuk mengatasi kesehatan, mengatasi keluhan rasa sakit dan dapat mengatasi kelelahan. Hasil tersebut sesuai dengan pendapatnya Sa'roni \& Graha (2019) masase terapi cedera olahraga efektif terhadap penurunan rasa nyeri. Selain itu Hernowo \& Ambardini (2019) juga menyatakan bahwa terapi kombinasi masase dan terapi latihan PNF efektif terhadap pemulihan, nyeri dan fungsi gerak cedera panggul.

Sesuai pendapatnya Juliabtri, Nurfianti \& Maulana (2015. P249) masase merupakan hal yang menyenangkan, karena dapat membantu tubuh dan pikiran untuk memproduksi endorphin yang merupakan penghilang rasa sakit yang dialami oleh tubuh. Sedangkan pendapatnya Kaur (2012) bahwa masase memiliki efek mekanis yang akan memperbaiki sirkulasi, menghilangkan produk limbah dari tubuh, meningkatkan mobilitas sendi dan mengurangi ketegangan otot. Wahida \& Khusniyah (2012) dengan melakukan massage akan mempengaruhi kerja korteks serebral sehingga menghasilkan persepsi positif dan relaksasi, secara tidak langsung membantu keseimbangan homeostatis tubuh melalui jalan HPA Axis, untuk menghasilkan Coticitropin Releasing Factor (CRF).

$\mathrm{CRF}$ dapat merangsang kelenjar pituitary untuk meneurunkan produksi ACTH yang akan meningkatkan memproduksi endorprin yang kemudian menurunkan produksi kortisol dan hormon-hormon stres lainnya, sehingga tubuh akan menjadi rileks. Saat relaksasi kebutuhan oksigen dalam tubuh akan menurun diikuti penurunan otot-otot tubuh, aliran darah akan lancar, neurotransmiter penenang akan dilepaskan dan sistem saraf akan bekerja secara baik sehingga menimbulkan perasaan tenang dan nyaman (Juliabtri, Nurfianti \& Maulana 2015. P.262). Nugroho, Asrin, \& Sarwono (2012) mengemukakan bahwa masase yang dilakukan secara teratur bisa menurunkan tekanan darah sistolik dan diastolik, menurunkan kadar hormon stres cortisol, menurunkan sumber-sumber depresi dan kecemasan, sehingga tekanan darah akan terus turun dan fungsi tubuh semakin membaik.

Bentuk materi dan urutan teknik masase kesehatan berbasis produktivitas kerja bagi disabilitas tuna daksa merupakan modifikasi bentuk masase antara teknik masase olahraga (sport massage) dan masase sirkulasi (circulo massage) yang sifatnya rehabilitasi atau terapi ke teknik masase yang sifatnya kesehatan, akan tetapi tidak merubah teknik yang sudah ada di dalam kedua jenis masase tersebut. Spesifikasi bentuk masase kesehatan terdiri dari tiga posisi, yaitu telungkup, terlentang dan duduk. Pada posisi telungkup dimulai dari sebelah kiri diawali dari bawah yaitu bagian kaki kiri. Pada posisi terlentang masase diawali dari kaki dan jari-jari kaki sebelah kiri. Sedangkan pada posisi duduk masase diawali dari bahu sebelah kanan. Teknik dari ketiga posisi tersebut menggunakan friction, petrisase, tapotement, walken, skin rolling dan effleurage.

\section{SIMPULAN}

Berdasarkan hasil penelitian dapat ditarik simpulan bahwa para ahli menyatakan bentuk masase kesehatan sangat baik dan layak untuk diterapkan. Selain itu masase yang diterapkan efektif untuk meningkatkan produktivitas kerja dan meningkatkan kesehatan dan 
mengatasi keluhan rasa sakit. Spesifikasi hasil dalam mengembangkan bentuk masase kesehatan diantaranya: 1) Posisi badan pada masase kesehatan terdiri dari tiga posisi, yaitu telungkup, terlentang dan duduk. 2) Pada posisi telungkup dimulai dari sebelah kiri diawali dari bawah yaitu bagian kaki kiri. 3) Pada posisi terlentang masase diawali dari kaki dan jari-jari kaki sebelah kiri. 4) Pada posisi duduk masase diawali dari bahu sebelah kanan., dan 5) Teknik dari ketiga posisi tersebut menggunakan friction, petrisase, tapotement, walken, skin rolling, dan effleurage.

Selain itu para ahli memberikan masukan bahwa bentuk masase kesehatan dapat dibuat tiga porsi atau jenis bentuk masase berdasarkan jumlah teknik, waktu dan jenis kecacatannya, diantaranya: 1) bentuk masase yang tekniknya menyeluruh, yang waktunya 60 menit dan digunakan untuk tuna daksa ringan., 2) bentuk masase yang tekniknya sebagian atau setengah, yang waktunya 30 menit dan digunakan untuk tuna daksa sedang., dan 3) bentuk masase yang tekniknya sedikit, yang waktunya 15 menit dan digunakan untuk tuna daksa ganda.

\section{DAFTAR PUSTAKA}

Albarracin D, Johnson BT, Fishbein M, Muellerleile PA. (2001). Theories of reasoned action and planned behavior as models of condom use: A meta-analysis. Pshchological Bulletin

Deswanto K. (2004). Studi Persepsi Masyarakat terhadap Tingkat Kepentingan Penyediaan Ruang Terbuka Publik (RTP) yang Aksessibel Bagi Masyarakat Difabel (Studi Kasus :Alun-Alun Utara Solo). Universitas Diponegoro. Semarang.

Djati S.P. (2009). Pengaruh Variabel-Variabel Motivasi Terhadap Produktivitas Tenaga Kerja Karyawan pada Industri Rumah Tangga di Kabupaten Sidoarjo. Jurnal Manajemen dan Kewirausahaan Vol. 1, No. 1, September 1999 : 22 - 35. Universitas Kristen Petra Surabaya.

Hasibuan, M.S.P. (2009). Organisasi dan Motivasi, Dasar Peningkatan Produktivitas. Jakarta: Bumi Aksara Putra

Hernowo, D.W., \& Ambardini, R.L (2019). Efektivitas Terapi Kombinasi Masase Frirage dan Latihan PNF Terhadap Pemulihan Cedera Panggul. Jurnal MEDIKORA, Vol.XVIII No. 2 Oktober 2019, Hal 86-91.

Juliantri, V., Nurfianti A. dan Maulana, M.A. (2015). Efektivitas Massage Ekstremitas terhadap Perubahan Tekanan Darah pada Pasien Hipertensi di Klinik Pratama Universitas Tanjungpura. Jurnal Cerebellum. Volume 1 Nomor 3. Agustus 201.

Kaur , B. (2012). Effect Of Foot Massage And Reflexology On Physiological Parameters Of Critically Ill Patients. Nursing And Midwifery Research Journal, Vol. VIII (No. 3), 223-233.

Nugroho, Asrin, dan Sarwono. (2012). Efektifitas Pijat Refleksi Kaki dan Hipnoterapi Terhadap Penurunan Tekanan Darah Pada Pasien Hipertensi. Jurnal Ilmiah Kesehatan.

Purnama, R. (2008). Pengaruh Motivasi Kerja terhadap Produktivitas Kerja Karyawan pada Bagian Produksi CV. Epsilon Bandung. Jurnal Strategic, Volume 7, Nomor 14, September 2008. 
Ravianto. (2005). Produktivitas dan Manajemen. SIUP, Jakarta.

Riyanto, J. (2006). Produktivitas dan Tenaga Kerja. SIUP, Jakarta.

Sa'roni. A.S \& Graha. A.S., (2019). Efektifitas Masase Terapi Cedera Olahraga Terhadap Nyeri Tumit Dan Nyeri Otot Tibialis Pada Atlet Futsal SMA Negeri 1 Ciamis. Jurnal MEDIKORA, Vol.XVIII No. 2 Oktober 2019, Hal 56-63.

Sarwono (2007). Sosiologi Kesehatan Beberapa Konsep Beserta Aplikasinya. Yogyakarta: Gadjah Mada University Press

Sedarmayanti. (2001). Sumber Daya Manusia dan Produktivitas Kerja. Bandung: Mandar Maju.

Skinner TC, Jhon M, Hampson, SE (2000). Social support and personal models of diabetes as predictors of self-care and well-being: A longitudinal study of adolescents with diabetes. Journal of Pediatric Psychology.

Sugiyono (2018). Penyusunan Proposal Penelitian UNY. Disampaikan dalam Workshop Penyegaran Penyususunan Proposal Penelitian pada Tanggal 14 Januari 2018 di UNY.

Sulaeman E.S. (2016). Pembelajaran Model Dan Teori Perilaku Kesehatan Konsep dan Aplikasi. Surakarta: UNS Press 